\title{
Endoscopic transgastric cholecystectomy during direct endoscopic necrosectomy for walled-off necrosis of the pancreas
}

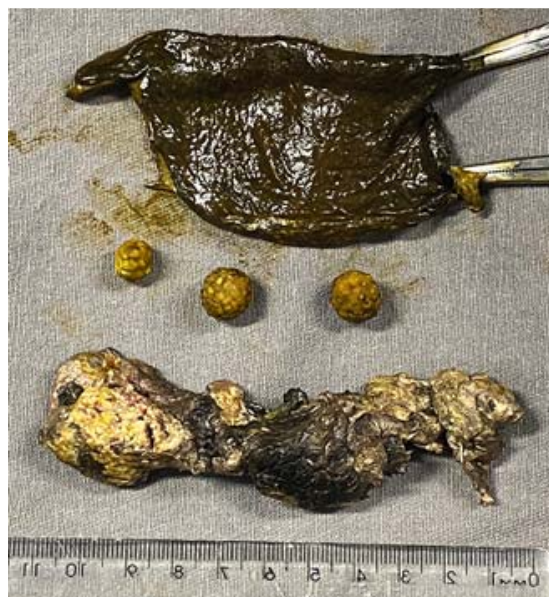

- Fig. 1 Photograph of the extracted gallbladder, the three stones it contained, and the result of the necrosectomy.

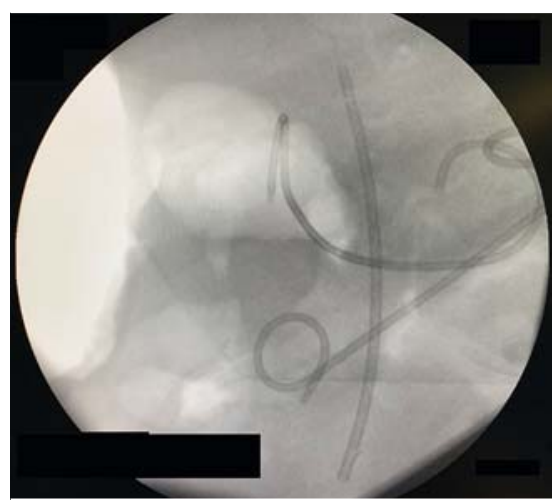

Fig. 2 Fluoroscopic image showing the $10-$ Fr transgastric plastic double-pigtail stents placed on the gallbladder bed and at the former location of the pancreas.

Pancreatic fluid collections may occur as a result of acute pancreatitis, although many spontaneously resolve. However, a subset of patients with necrotizing pancreatitis may develop symptomatic welldefined necrotic collections, classified as walled-off necrosis (WON) [1,2]

A 54-year-old man who was admitted with moderately severe acute biliary pancreatitis made a good response to treatment and was discharged 4 days after

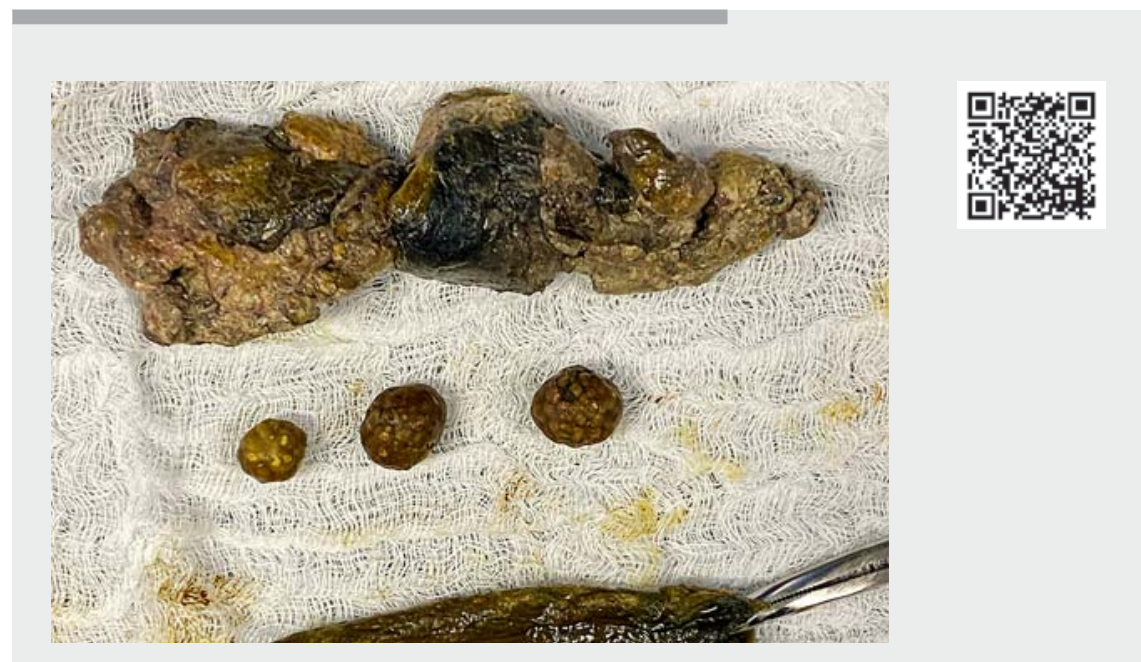

$\checkmark$ Video 1 Video showing a patient with walled-off necrosis of the pancreas who underwent transgastric cholecystectomy during his third direct endoscopic necrosectomy.

admission. However, 60 days later, he returned with abdominal pain, vomiting, and delayed gastric outflow. A computed tomography (CT) scan showed an encapsulated heterogeneous pancreatic collection, measuring $11 \times 18 \mathrm{~cm}$, compatible with WON, and endoscopic treatment was chosen. Endoscopic ultrasound (EUS)-guided drainage was performed, with insertion of a $10-\mathrm{mm}, 10-\mathrm{cm}$ transgastric self-expandable metal stent (SEMS); however, he continued to have an intermittent fever and worsened clinically.

In the following weeks, he underwent two sessions of direct endoscopic necrosectomy, obtaining partial clinical improvement after the second. Magnetic resonance cholangiopancreatography (MRCP) 3 weeks after the EUS drainage showed intrahepatic biliary duct dilatation and a common bile duct filling defect. Endoscopic retrograde cholangiopancreatography (ERCP) was then performed, which showed a cystic duct/infundibulum biliary fistula and a small distal choledocholithiasis. Biliary sphinc- terotomy was performed, which allowed removal of a biliary stone and insertion of a $10-\mathrm{Fr}, 10-\mathrm{cm}$ biliary plastic stent. Pancreatography was then performed, which showed complete disruption of the main pancreatic duct with contrast extravasation (type IV-A Lera-Proença) [3]. A large amount of necrotic content and bile output through the necrosis was evident. Direct endoscopic necrosectomy was performed with a snare, and a large piece of tissue was removed along with the necrotic remains. This piece of tissue was removed through the mouth and was found to be the gallbladder, with three biliary stones contained within it ( Fig. 1). Upon review, it was possible to identify the gallbladder bed and the former location of the pancreas, with no evidence of bleeding. Fluoroscopy showed air in the vesicle bed, but no signs of a pneumoperitoneum. We therefore placed 10-Fr transgastric plastic doublepigtail stents at the gallbladder bed and the former location of pancreas ( $>$ Fig. 2; - Video 1). The patient progressed well, showing clinical and laboratory improve- 
ment, and was discharged 7 days after the procedure.

Endoscopy_UCTN_Code_CCL_1AZ_2AH

\section{Competing interests}

The authors declare that they have no conflict of interest.

The authors

Marcos Eduardo Lera dos Santos ${ }^{1}$, Igor Braga Ribeiro' ${ }^{\circledR}$, Igor Mendonça Proença' ${ }^{1}$, Gabriel Mayo Vieira de Souza ${ }^{1}$, Diogo Turiani Hourneaux de Moura ${ }^{1,2} \odot$, Sergio Eiji Matuguma ${ }^{1}$, Eduardo Guimarães Hourneaux de Moura ${ }^{1} \odot$

1 Gastrointestinal Endoscopy Unit, Hospital das Clínicas da Faculdade de Medicina da Universidade de São Paulo, São Paulo, Brazil

2 Division of Gastroenterology, Hepatology and Endoscopy, Brigham and Women's Hospital - Harvard Medical School, Boston, Massachusetts, USA

\section{Corresponding author}

\section{Igor Braga Ribeiro, MD}

Av. Dr Enéas de Carvalho Aguiar, 225, $6^{\circ}$ andar, bloco 3, Cerqueira Cesar. São Paulo - SP, 05403-010, Brazil igorbraga1@gmail.com

\section{References}

[1] Messallam AA, Adler DG, Shah RJ et al. Direct endoscopic necrosectomy with and without hydrogen peroxide for walled-off pancreatic necrosis Am J Gastroenterol 2020. doi:10.14309/ajg.0000000000000987

[2] Connor S, Alexakis N, Raraty MGT et al. Early and late complications after pancreatic necrosectomy. Surgery 2005; 137: 499-505

[3] Proença IM, dos Santos MEL, de Moura DTH et al. Role of pancreatography in the endoscopic management of encapsulated pancreatic collections - review and new proposed classification. World J Gastroenterol 2020; 26: 7104-7117
Bibliography

Endoscopy 2022; 54: E79-E80

DOI 10.1055/a-1388-6254

ISSN 0013-726X

published online 15.3.2021

(C) 2021. Thieme. All rights reserved.

Georg Thieme Verlag KG, Rüdigerstraße 14,

70469 Stuttgart, Germany

\section{ENDOSCOPY E-VIDEOS}

https://eref.thieme.de/e-videos

口回回 Endoscopy E-Videos is an open access online section, 回: reporting on interesting cases and new techniques in gastroenterological endoscopy. All papers include a high quality video and all contributions are freely accessible online. Processing charges apply (currently EUR 375), discounts and wavers acc. to HINARI are available.

This section has its own submission website at https://mc.manuscriptcentral.com/e-videos 